\title{
Potential of Producing Hydrogen Gas from Straw by Anaerobic Thermal Shocked Biological Sludge to Create Clean Energy
}

\author{
$\mathrm{Nam} \mathrm{NH}$ \\ Department of Environment, Hanoi University of Mining and Geology, Vietnam
}

*Corresponding author: Nam NH, Department of Environment, Hanoi University of Mining and Geology, Vietnam, Tel: (+84)1277093096, E-mail: nguyenhoangnam@humg.edu.vn

Citation: Nam NH (2018) Potential of Producing Hydrogen Gas from Straw by Anaerobic Thermal Shocked Biological Sludge to Create Clean Energy. J Environ Pollut Control 1(1): 103. doi: 10.15744/2639-9288.1.103

Received Date: February 27, 2018 Accepted Date: September 11, 2018 Published Date: September 13, 2018

\begin{abstract}
Hydrogen gas has been used widely in industrial aspect, especially as clean energy. On one hand, it reduces the dependency on fossil fuels; on the other hand it solves the environmental polluting issue and also reduces the greenhouse gases emitted to the environment. Producing hydrogen by chemical and physical methods require higher fee and investment. Producing hydrogen from renewable biomass, especially agricultural waste such as straws, can produce with low cost and decrease the amount of agricultural waste and pollutions. This article introduces the result of the beginning research to produce hydrogen gas from straw using biotechnology. Bacteria source to hydrolyze cellulose to median product such á glucose, lactate, acetate ethanol... and hydrogen gas í cultivated and enriched from biological sludge, taken from water spinach field and grow in medium 1658 MMS with glucose added straw (M2) and not added straw (M1). Hydrogen gas was introduced to growing environment to remove $\mathrm{O}_{2}$ and create suitable environment for bacteria to grow. Thermal shock in $70-80^{\circ} \mathrm{C}$ condition in $72 \mathrm{~h}$, to exclude unbeneficial bacteria for hydrogen production and create suitable environment for bacterial benefit to fermentation to hydrogen to develop, then stabilize at $37^{\circ} \mathrm{C}$ in 20 days. Microbes retrieved from $\mathrm{M} 2$ is used to hydrolyze straws by diluting it with nutrient solution at ratio 1: 4 . Adding straw to the solution, proceed fermentation in 2 phases, phase 1 with straw content $33,3 \mathrm{~g} / \mathrm{L}$ and phase 2 with straw content $130 \mathrm{~g} / \mathrm{L}$, in thermal shocked condition at between $55-60{ }^{\circ} \mathrm{C}$. In fermentation, straw produce hydrogen above 50 days, dissolve organic content in bioreactor in phase 2 indicate that total amount of organic content is $6674.79 \pm 1397.21 \mathrm{mg} / \mathrm{L}$, methanol is $303.13 \pm 108.95 \mathrm{mg} / \mathrm{L}$. Hydrogen content in fermentation at phase 1 reached $6 \%$ and at phase 2 reached $17,82 \%$. Growing thermophilic anaerobic bacteria from biological sludge thermal shocked for fermentation of straw to produce hydrogen, starting point shows that it is simple, economical comparing to other biotechnology of producing hydrogen and can be continued for industrial application
\end{abstract}

Keywords: Straw; Hydrogen; Bacteria; Thermal shock

\section{Introduction}

Hydrogen is a sustainable clean fuel source and considered to be the energy source of the future [1]. Around the globe, there are many hydrogen producing methods such as chemical method, converting hydrocarbon (fossil fuel, biomass) by heat method, electrolysis method, biological method, nano technology [2-5]. However, each method has different pros and cons. Chemical method is simple, easily performed; yet require high investment expense, suitable for producing a small amount in the laboratory. The chemical-physical method is highly economical efficient, using natural gases but require high investment, operation and maintenance. Electrolysis and using nano technology has the best advantage is utilizing the infinite energy of the sun, material of the inflow is water, high efficiency, however initial investment is quite large [6,7]. The biological method is relatively new, has many potential but still remain in experimental phase [7].

Vietnam is a manufactural country and export rice at the top of the world, following by is a large amount of remaining straw, effecting the environment. Study to treat and utilize straw - agricultural waste, producing hydrogen by biological technology not only utilize straw as a clean energy source, but also has high application in industrial as well as daily lives; simultaneously reduce environmental pollution, green house effects...

Among all the producing $\mathrm{H}_{2}$ method, anaerobic fermentation is available, hydrogen producing rate is high and capable of using many organic waste as substrate [8-10]. 


\section{Materials and Methods}

\section{Experimental setup}

The experimental set-up is shown in Figure 1. The laboratory bioreactor (liquid volume $10 \mathrm{~L}$ ) was made of glass and was temperature controlled at $50-60{ }^{\circ} \mathrm{C}$ by running water through the outer mantle of the reactor. The biologically active reactor volume was $8 \mathrm{~L}$, containing smoothly grinded straw and enriched bacteria as well as nutrient solution. Ar is continuously added to bioreactor as carrier to lead the air product out, produced gas is leaded to a saturated $\mathrm{Ca}(\mathrm{OH})_{2}$ bath to remove $\mathrm{H}_{2} \mathrm{~S}$, $\mathrm{CO}_{2}$, the system is continuously operated in 60 days' time.

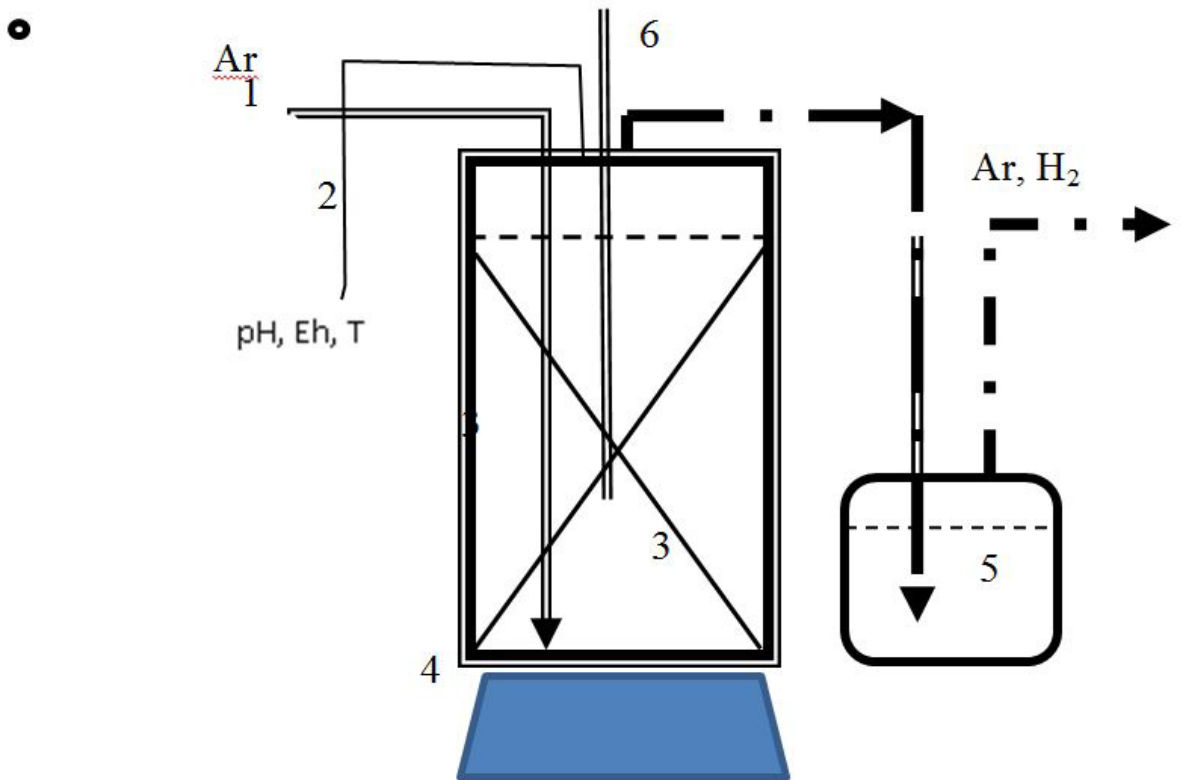

Figure 1: Layout of the biological hydrogen producing from straw reactor (1: Ar gas; 2 : measurement of $\mathrm{pH}$ temperature, redox potential; 3: biological reactor; 4: heating magnetic stirrer; 5: lime cream tank; 6: Sample taken point)

The $\mathrm{pH}$-electrode, redox-electrode, Temperature-electrode is inserted into the bioreactor and is connected to the meter online. The adjustment of the $\mathrm{pH}$ of the solution through the solution $\mathrm{NaOH}$ and $\mathrm{H}_{2} \mathrm{SO}_{4}$ in the input.

Medium: Enriching thermophilic anaerobic bacteria producing hydrogen gas as well as fermenting straws in bioreactor using nutrient solution with content indicated in Table 1 and 2 . And isolation environment is shown in Table 3 . All chemicals used were of extra pure quality and supplied by Merck (Darmstadt, Germany).

\begin{tabular}{|c|c|c|}
\hline Nr. & Substance & Concentration \\
\hline 01 & $\mathrm{NaCl}$ & $6,93(\mathrm{~g} / \mathrm{l})$ \\
\hline 02 & $\mathrm{MgSO}_{4} \cdot 7 \mathrm{H}_{2} \mathrm{O}$ & $1,75(\mathrm{~g} / \mathrm{l})$ \\
\hline 03 & $\mathrm{MgCl}_{2} \cdot 6 \mathrm{H}_{2} \mathrm{O}$ & $1,38(\mathrm{~g} / \mathrm{l})$ \\
\hline 04 & $\mathrm{KCl}$ & $0,16(\mathrm{~g} / \mathrm{l})$ \\
\hline 05 & $\mathrm{NaBr}:$ & $25,0(\mathrm{mg} / \mathrm{l})$ \\
\hline 06 & $\mathrm{H}_{3} \mathrm{BO}_{3}$ & $7,5(\mathrm{mg} / \mathrm{l})$ \\
\hline 07 & $\mathrm{SrCl}_{2} \cdot 6 \mathrm{H}_{2} \mathrm{O}$ & $3,8(\mathrm{mg} / \mathrm{l})$ \\
\hline 08 & $\mathrm{KI}_{2}$ & $0,025(\mathrm{mg} / \mathrm{l})$ \\
\hline 09 & $\mathrm{CaCl}_{2}$ & $0,38(\mathrm{~g} / \mathrm{l})$ \\
\hline 10 & $\mathrm{KH}_{2} \mathrm{PO}_{4}:$ & $0,5(\mathrm{~g} / \mathrm{l})$ \\
\hline 11 & $\mathrm{Na}_{2} \mathrm{~S}_{9} 9 \mathrm{H}_{2} \mathrm{O}$ & $0,5(\mathrm{~g} / \mathrm{l})$ \\
\hline 12 & $\left(\mathrm{NH}_{4}\right)_{2} \mathrm{Ni}\left(\mathrm{SO}_{4}\right)_{2}$ & $2,0(\mathrm{mg} / \mathrm{l})$ \\
\hline 13 & $\mathrm{Resazurin}_{2}$ & $1,0(\mathrm{mg} / \mathrm{l})$ \\
\hline 14 & Wolfe mineral solution & $15,0(\mathrm{ml} / \mathrm{l})$ \\
\hline 15 & Starch $_{2}$ & $5(\mathrm{~g} / \mathrm{l})$ \\
\hline
\end{tabular}

Adjust final pH to 6.5 with $\mathrm{H}_{2} \mathrm{SO}_{4}$. Prepare anaerobically under $80 \% \mathrm{~N}_{2}, 20 \% \mathrm{CO}_{2}$. Autoclave.

Table 1: ATCC medium 1658 


\begin{tabular}{|c|c|c|}
\hline Nr. & Substance & Concentration \\
\hline 01 & $\mathrm{~N}\left(\mathrm{CH}_{2} \mathrm{CO}_{2} \mathrm{H}\right)_{3}$ & $1,5(\mathrm{~g} / \mathrm{l})$ \\
\hline 02 & $\mathrm{MgSO}_{4} \cdot 7 \mathrm{H}_{2} \mathrm{O}$ & $3.0(\mathrm{~g} / \mathrm{l})$ \\
\hline 03 & $\mathrm{MnSO}_{4} \cdot \mathrm{H}_{2} \mathrm{O}$ & $0.5(\mathrm{~g} / \mathrm{l})$ \\
\hline 04 & $\mathrm{NaCl}$ & $1,0(\mathrm{~g} / \mathrm{l})$ \\
\hline 05 & $\mathrm{FeSO}_{4} \cdot 7 \mathrm{H}_{2} \mathrm{O}$ & $0.1(\mathrm{~g} / \mathrm{l})$ \\
\hline 06 & $\mathrm{CoCl}_{2} \cdot 6 \mathrm{H}_{2} \mathrm{O}$ & $0.1(\mathrm{~g} / \mathrm{l})$ \\
\hline 07 & $\mathrm{CaCl}_{2}$ & $0.1(\mathrm{~g} / \mathrm{l})$ \\
\hline 08 & $\mathrm{ZnSO}_{4} \cdot 7 \mathrm{H}_{2} \mathrm{O}$ & $0.1(\mathrm{~g} / \mathrm{l})$ \\
\hline 09 & $\mathrm{CuSO}_{4} \cdot 5 \mathrm{H}_{2} \mathrm{O}$ & $0.01(\mathrm{~g} / \mathrm{l})$ \\
\hline 10 & $\mathrm{AlK}\left(\mathrm{SO}_{4}\right)_{2} \cdot 12 \mathrm{H}_{2} \mathrm{O}$ & $0.01(\mathrm{~g} / \mathrm{l})$ \\
\hline 11 & $\mathrm{H}_{3} \mathrm{BO}_{3}$ & $0.01(\mathrm{~g} / \mathrm{l})$ \\
\hline 12 & $\mathrm{Na}_{2} \mathrm{MoO}_{4} \cdot 2 \mathrm{H}_{2} \mathrm{O}$ & $0.01(\mathrm{~g} / \mathrm{l})$ \\
\hline
\end{tabular}

Adjust to $\mathrm{pH} 6.5$ with $\mathrm{KOH}$ to dissolve the compound. Table 2: Wolfe's Mineral Solution: Available from ATCC as a sterile ready-to-use liquid

(Trace Mineral Supplement, catalog no. MD-TMS.)

\begin{tabular}{|c|c|c|}
\hline Nr. & Substance & Concentration \\
\hline 01 & $\mathrm{C}_{6} \mathrm{H}_{12} \mathrm{O}_{6}$ & $10.0(\mathrm{~g} / \mathrm{l})$ \\
\hline 02 & $\mathrm{NaCl}$ & $5.0(\mathrm{~g} / \mathrm{l})$ \\
\hline 03 & Yeast & $5.0(\mathrm{~g} / \mathrm{l})$ \\
\hline 04 & $\mathrm{FeSO}_{4} \cdot 7 \mathrm{H}_{2} \mathrm{O}$ & $0.5(\mathrm{~g} / \mathrm{l})$ \\
\hline 05 & Agar & $18.0(\mathrm{~g} / \mathrm{l})$ \\
\hline
\end{tabular}

Cultivation isolation of bacteria: Before experiment, Thermophilic anaerobic bacteria that produce hydrogen was taken from biological sludge in water morning glory field, centrifuged at rate 8500 rounds/min in 15 minutes, sludge afterward was thermal shock at $60^{\circ} \mathrm{C}$ in 1 hour.

After pretreatment, bacteria were cultivated in the enriching environment: $200 \mathrm{~g}$ centrifuged sludge $+600 \mathrm{ml}$ nutrient solution (according to ATCC medium: 1658 MMS).

Solution was stirred and heated in range of $70-80{ }^{\circ} \mathrm{C}$ simultaneously add $\mathrm{H}_{2}$ continuously in 72 hours aiming to create a suitable environment before put into stirrer at rate 170 round per min in moderation at $37^{\circ} \mathrm{C}$ in 20 days.

Portion of cultivated and enriched samples:

- Sample 1 (M1): 200 g centrifuged, heat shocked sludge $+600 \mathrm{ml}$ nutrient +5 g glucose.

- Sample 2 (M2): $200 \mathrm{~g}$ centrifuged, heat shocked sludge $+600 \mathrm{ml}$ nutrient $+5 \mathrm{~g}$ glucose $+5 \mathrm{~g}$ straw.

Dilute original sample by nutrient solution in ratio of $1: 4$, add $20 \mathrm{~g}$ dry minced straw into the sample, put into thermostats at $60{ }^{\circ} \mathrm{C}$ in 30 days. Bacteria sample after cultivated was mixed with $250 \mathrm{~g}$ straw and $5 \mathrm{~L}$ nutrient in bioreactor, kept in range $55-60{ }^{\circ} \mathrm{C}$.

Sampling and analysis: Gas sample is taken once per day in the outflow of $\mathrm{Ca}(\mathrm{OH})_{2}$ saturated bath. Organic compounds analysis sample is taken directly in reactor.

$\mathrm{MeOH}$ was determined with a gas chromatograph (Haedspace-Gaschromatographie) using a method adapted from (Uematsu et al. 2002). Soluble organic compounds such as Glucose, ethanol, acetate, lactate... in sample was analyzed with high performance liquid chromatography (HPLC 1100, Agilent 1200, using column $87 \mathrm{H}$ with pumping pressure 60 bar, temperature $60^{\circ} \mathrm{C}$ with flowrate 0.6 $\mathrm{ml} / \mathrm{min}$, detector RID. Gas phase composition was determined with a gas chromatograph (Fisons Instruments GC 8000) equipped with two columns: $1.5 \mathrm{~m}$ X Y4' Teflon packed with Chromosorb 108 (60 to 80 mesh), and $1.2 \mathrm{~m}$ X Yirr stainless-steel packed with mol. sieve 5A (60 to 80 mesh). Hydrogen, methane, nitrogen were determined with a gas chromatograph equipped with detector (WLD), using a method adapted from Köhler 2000. Protein was determined with photometrically using a method adapter from Bradford 1976. Hydrogen retention time is measured with instruments for interpenetrated flow vessels.

\section{Results and Discussions}

\section{Isolate anaerobic thermophilic hydrogen producing bacteria}

To produce hydrogen from straw biologically, it require hydrogen producing bacteria. Therefore the first step is to isolate this bacteria specie [11]. Enrichment methods using acid, chemical, wet heat-, dry heat-shock, freezing and thawing was carried out for cattle manure sludge, and increased $\mathrm{H}_{2}$ production using acid pretreatment was 1.9-9.8 times greater compared to control sludge [12]. A 
comparative study was made across acid, heat and chloroform treatment on sewage sludge during immobilized $\mathrm{H}_{2}$ production in a mixed-culture under anaerobic conditions. Chloroform treatment inhibited hydrogen consuming bacteria, avoided fast conversion of $\mathrm{H}_{2}$ to acetic acid and repeated culture showed $\mathrm{H}_{2}$ production till 15 days [13]. Heat pretreatment was the best among other pretreatments (acid and base) for enriching $\mathrm{H}_{2}$ producing bacteria from anaerobic sludge [14]. The increased $\mathrm{H}_{2}$ production depends on the source of the seed sludge and the pretreatment method. Heat treatment is a simple, effective and practical method in comparison to other methods for enriching $\mathrm{H}_{2}$-producing bacteria from different seed source [14-17]. In this study, hydrogen producing bacteria was not used from biological waste but isolated from active sludge from water morning glory field, where contain communities of bacteria.

Figure 2 and 3 indicate the result of enriching anaerobic thermophilic bacteria from natural biological sludge in condition of thermal shocked, both straw added and non-straw-added. In thermal shocked condition, aerobic bacteria and some anaerobic bacteria that cannot adapt to high temperature do not exist; combine with aerating hydrogen into the cultivating environment, forming a suitable environment for hydrogen producing bacteria.

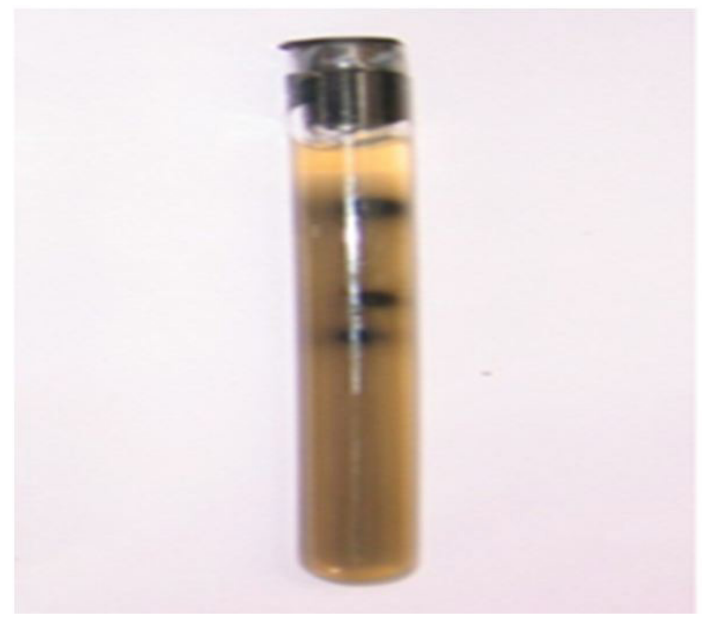

Figure 2: Sample of anaerobic thermophilic bacteria enriched in natural thermal shocked non adding straw environment (M1)

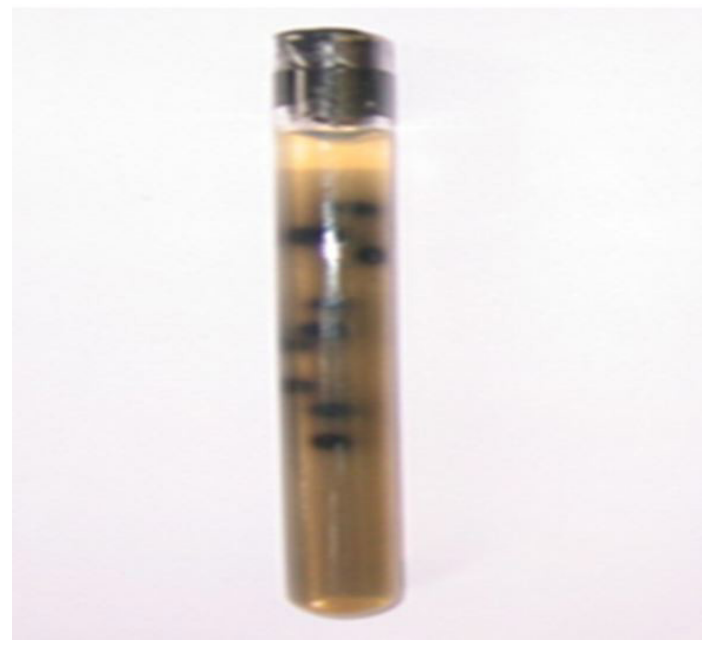

Figure 3: Sample of anaerobic thermophilic bacteria enriched in natural thermal shocked straw added environment (M2)

By adding straw to provide another carbon source, simultaneously create medium for bacteria activities, provide suitable condition for not only hydrogen producing bacteria but also cellulose hydrolysis bacteria and some other bacteria beneficial for producing hydrogen, therefore in the same cultivating condition, the amount of bacteria received in thermal shocked straw added sample (Figure 2) is higher than non-straw-added sample (Figure 3). Combine with the analysis result of hydrogen (Figure 4) produced in the cultivating process prove that in the sample exist hydrogen producing bacteria as stated in the aim, therefore, the product is continue to be used for the study process. As can be seen, thermal shocked used in this study is simply, using natural available bacteria, and using carbon source from agriculture waste to create low cost and industrial applicable comparing to using costly medium enrichment pretreatment method. This study utilize the natural bacteria source to clean the environment and providing clean energy source.

\section{Content of dissolved organic compound}

In the process of producing hydrogen from cellulose by biotechnology, the content of short chain organic compound such as glucose, lactate, acetate are the key of producing hydrogen, as well as methanol, ethanol can affect the process, thereby determine the 
efficiency of the fermentation producing hydrogen [18-20]. The mechanism of producing hydrogen using fermentation of straw are as follow [18-22]:

$$
\begin{aligned}
& \left(\mathrm{C}_{6} \mathrm{H}_{10} \mathrm{O}_{5}\right)+\mathrm{nH}_{2} \mathrm{O} \rightarrow \mathrm{nC}_{6} \mathrm{H}_{12} \mathrm{O}_{6} \quad(3-1) \\
& \mathrm{C}_{6} \mathrm{H}_{12} \mathrm{O}_{6}+2 \mathrm{H}_{2} \mathrm{O} \rightarrow 2 \mathrm{CH}_{3} \mathrm{COOH}+2 \mathrm{CO}_{2}+2 \mathrm{H}_{2} \quad(3-2) \\
& \mathrm{C}_{6} \mathrm{H}_{12} \mathrm{O}_{6} \rightarrow 2 \mathrm{CH} 3 \mathrm{CHOHCOOH} \quad(3-3) \\
& \mathrm{C}_{6} \mathrm{H}_{12} \mathrm{O}_{6} \rightarrow 2 \mathrm{CO}_{2}+2 \mathrm{CH}_{3} \mathrm{CH}_{2} \mathrm{OH} \quad(3-4)
\end{aligned}
$$

Glucose created during the hydrolysis process of cellulose from straw, is an important organic source to provide for the hydrogen producing process biologically [21]. Lactate was produced from glucose hydrolysis, on one hand, it was consumed to enhance the growth of bacteria, on the other hand it is used as organic source to provide for bacteria to produce hydrogen [23].

$$
\begin{aligned}
& \mathrm{CH}_{3} \mathrm{CHOHCOOH}+\mathrm{H}_{2} \mathrm{O} \rightarrow \mathrm{CH}_{3} \mathrm{COOH}+2 \mathrm{H}_{2}+\mathrm{CO}_{2} \\
& \mathrm{C}_{2} \mathrm{H}_{5} \mathrm{OH}+\mathrm{H}_{2} \mathrm{O} \rightarrow \mathrm{CH}_{3} \mathrm{COO}^{-}+\mathrm{H}^{+}+\mathrm{H}_{2}(3-6)
\end{aligned}
$$

Acetate is the co-product along with hydrogen in the fermentation process [12,24]. Methanol is formed through the reaction of bacteria with inflow material which are $\mathrm{H}_{2}$ and $\mathrm{CO}_{2}$, reacted as follow:

$$
\mathrm{CO}_{2}+3 \mathrm{H}_{2} \rightarrow \mathrm{CH}_{3} \mathrm{OH}+\mathrm{H}_{2} \mathrm{O}
$$

The reaction create methanol by the activities of bacteria is the final reaction in the biological reaction chain in the anaerobic environment using hydrogen as reducer $[22,24]$.

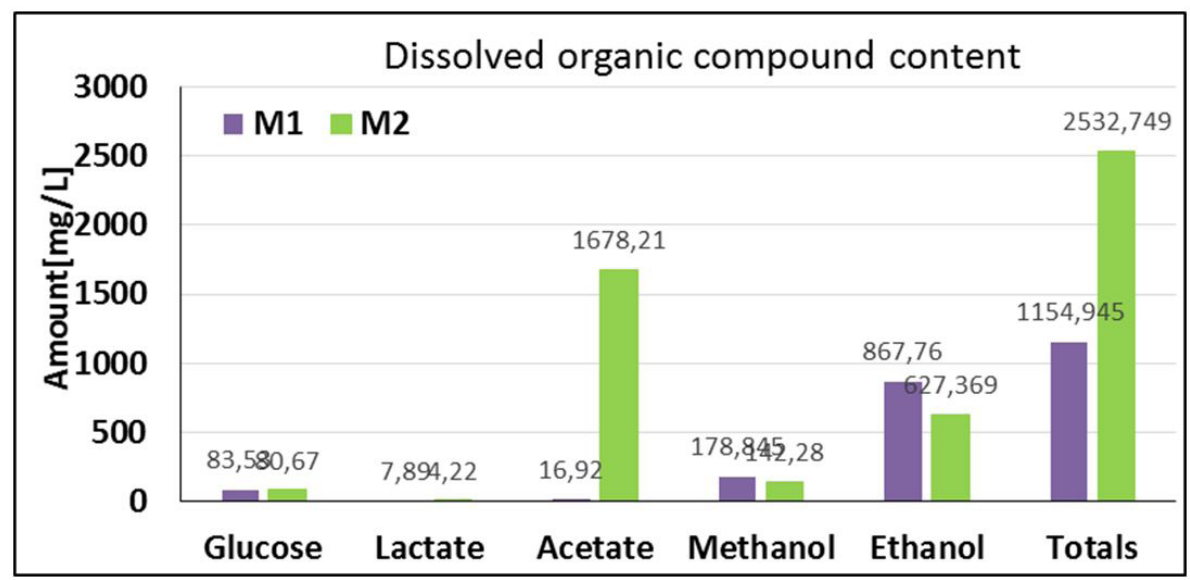

Figure 4: Amount of organic compound (sample 1) formed in condition of thermal shocked non-straw-added cultivation

The result of organic content analysis indicate that: in the environment of thermal shocked and non-straw-added sludge, after 20 days of cultivating bacteria, the total amount of dissolved organic compound in M2 is much higher than M1, proving the conversion of cellulose into dissolved organic compounds by bacteria occur well, especially converting into glucose, this product provides carbon source for bacteria producing hydrogen $[12,19,24]$. The glucose content in M1 is higher than M2 although M2 was added straw, the lactate content is also higher than M2, however, the amount of acetate is much lower than M2, this prove the hydrolysis of glucose to lactate and acetate is better, meaning producing more hydrogen.

The amount of methanol and ethanol is also higher than M2, caused by the created hydrogen reacting with CO2 to form methanol and some bacteria consume hydrogen in M2 is limited [24]. Also, in both samples, the ethanol rate is high, bacteria hydrolyzing glucose to ethanol is growing and the bacteria converting ethanol to hydrogen in this environment is unsuitable, the ethanol amount afterward is still high $[25,26]$.

It can be seen that the process of thermal shocking biological sludge in nature in condition of adding straw is a suitable environment, can enrich hydrogen producing bacteria from straw, thereby able to use them to ferment straw to produce hydrogen without consuming expensive hydrogen producing bacteria product.

\section{Efficiency of producing hydrogen in cultivating process}

The result of analyzing hydrogen received in different cultivating environments is shown in Figure 5.

The result indicates that, in the condition of cultivating without adding straw (M1), hydrogen does appear at first, even though with a small amount, its maximum rate reached $1,31 \%$, after that the produced amount decrease and after 46 days hydrogen does not appear. This proves in the sample exist hydrogen producing bacteria, however due to not adding straw as carbon source, the amount of carbon in the cultivating process decreased as the original carbon provided is only sufficient for bacteria to grow, therefore carbon is insufficient for the process of producing hydrogen 
In $\mathrm{M} 2$, the amount of $\mathrm{H}_{2}$ received in average of 4,633\%, much higher than $\mathrm{M} 1$ and it is released relatively equal during the whole process of cultivating. This proves in thermal shocked condition, not only removed bacteria harmful for producing hydrogen but also enriched aerobic producing hydrogen bacteria.

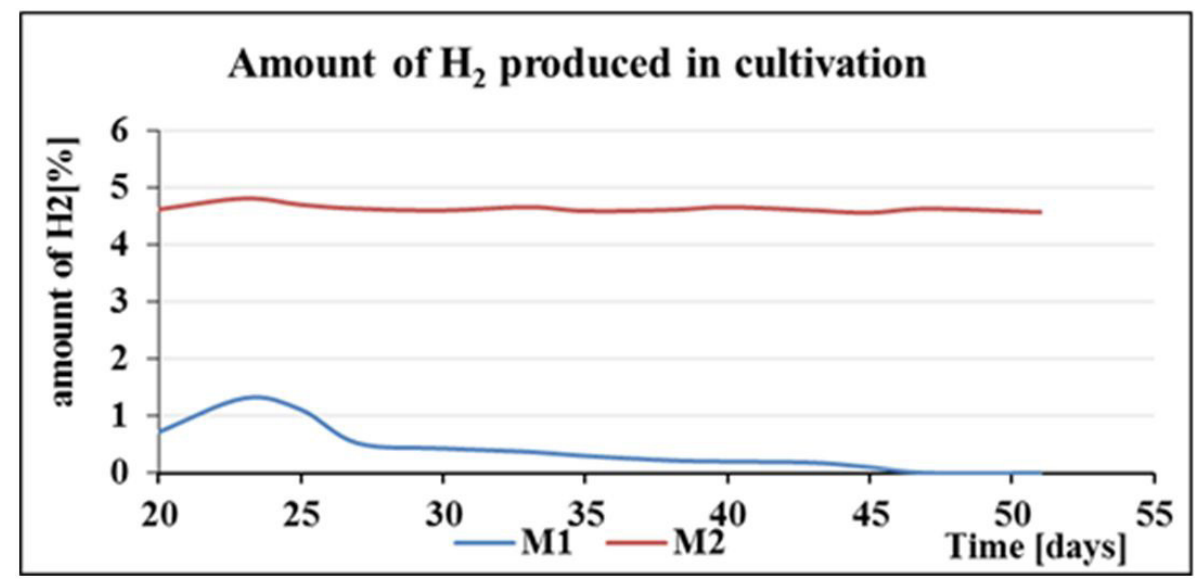

Figure 5: Ability to produce Hydro in different cultivating condition: thermal shocked without adding straw (M1) and thermal shocked straw added (M2), Duration 30 days (from 02-03 to 01-04 year 2017)

Adding straw to the environment not only provide carbon source for the process of fermenting straw producing hydrogen to increase the efficiency of producing hydrogen, but also create a suitable environment for enriching bacteria hydrolyzing cellulose into glucose, forming a medium for bacteria activities, especially favorable for hydrogen producing bacteria to grow. Therefore the condition of M2 can result in bacteria serve the process of producing hydrogen and produce hydrogen from straw. In the following research, experiments are conducted using bacteria cultivated in M2.

\section{Amount of dissolved organic compound and efficiency of producing hydrogen in bioreactor}

Bacteria were taken from M2, afterward diluted by nutrient solution, adding minced straw with original amount of 33,33g/l, temperature during the fermentation is kept at $55-60^{\circ} \mathrm{C}$. After 25 days of operating the bioreactor, continue adding straw into the reactor with total amount of $130 \mathrm{~g} / \mathrm{l}$, aiming to enhance the carbon source for the system.

The results of analyzing dissolved organic compound indicates that (Figure 6), when increase the amount of straw in the reactor, the total amount of organic compound in the bioreactor measured is very high, its value reached 6674,79 $\pm 1397.21 \mathrm{mg} / \mathrm{lmuch}$ higher than original $(2532,75 \mathrm{mg} / \mathrm{l})$, this shows the positive efficiency of adding a large amount of straw. Glucose content reached $4353,64 \pm 1076.32 \mathrm{mg} / \mathrm{l}$, this shows that the cellulose decomposing bacteria has adapted and operated productively, play an important role in creating carbon source for producing hydrogen by bacteria. However, glucose in this condition is much greater comparing to glucose content in the first phase, a part of glucose is transforms into lactate, a part transforms into acetate (1488.04 $\pm 487.64 \mathrm{mg} / \mathrm{L}$ ) as well as ethanol to produce hydrogen. Result of lactate content indicates that its amount is higher than the first phase, but lower than acetate and ethanol, this shows the conversion of lactate into acetate and producing hydrogen is very good, combine with the content of ethanol shows that in this phase the ethanol content is lower than the first phase which indicate the process of producing hydrogen from ethanol occur very well.

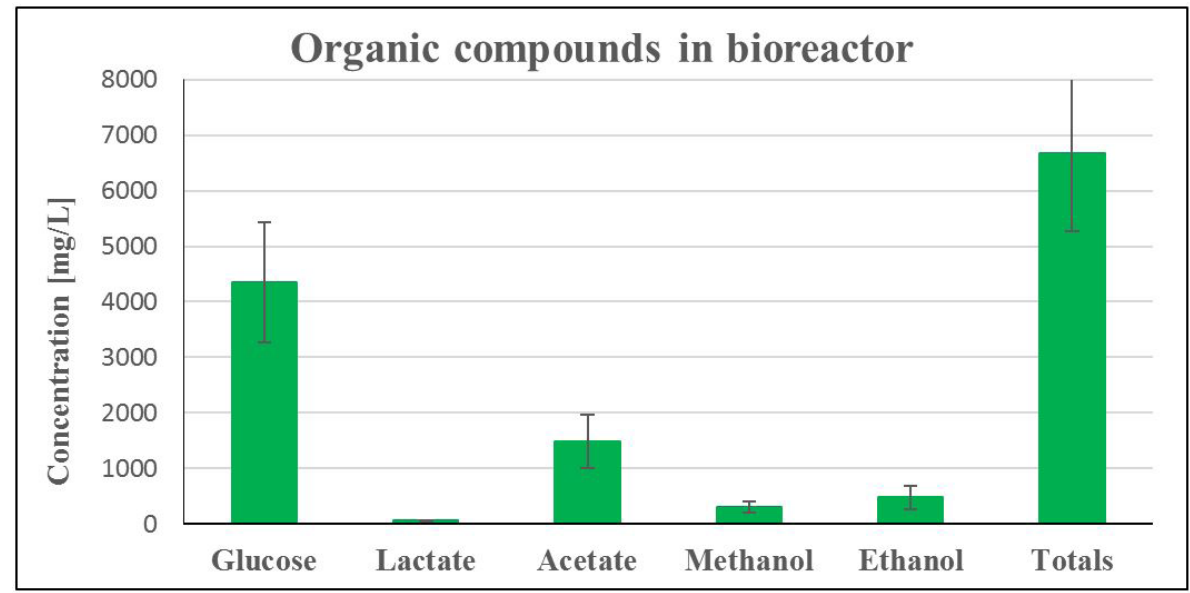

Figure 6: Content of organic compounds in bioreactor during fermentation producing Hydrogen 
Based on the transformation of organic compound combine with analysis results of $\mathrm{H}_{2}$ content (Figure 7) shows that, during the first period of the operating process in the first 5 days, hydrogen was not formed, in the next 20 days, hydrogen was produced in stability, cover approximate 5 to $6 \%$, this is strongly related to the content of dissolved organic compounds especially glucose (Zhang et al. 2006).

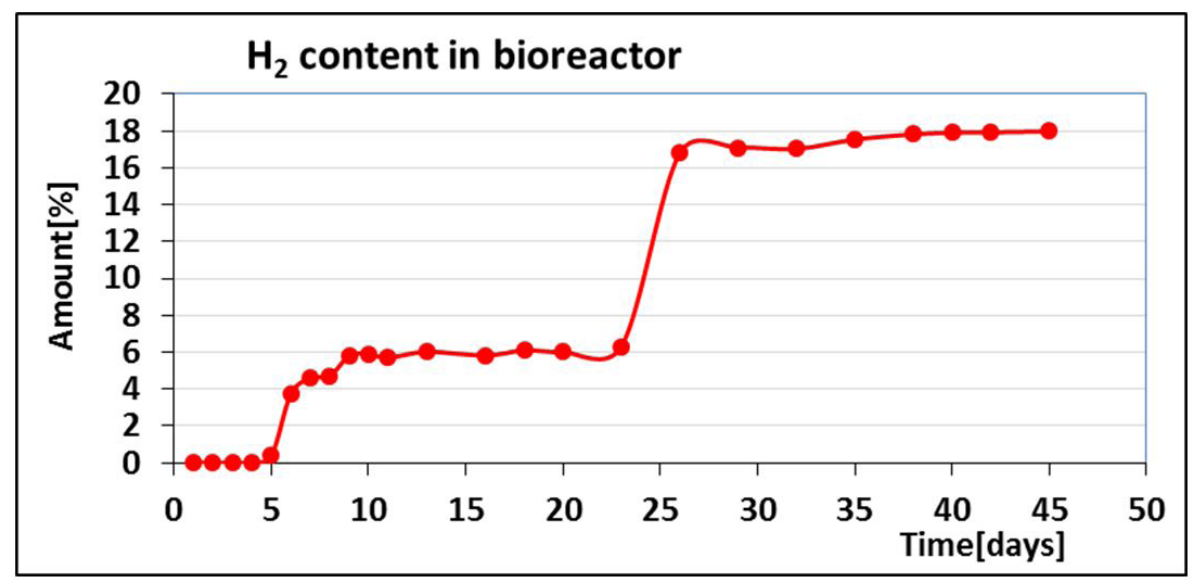

Figure 7: Result of Hydrogen content in bioreactor in fermentation

With the low amount of organic compound capable of producing hydrogen, lead to low amount of hydrogen produced due to equilibrium [19]. In the later phase, by adding straw, after a period to stabilize the environment, glucose as well as acetate, ethanol increased, the amount of $\mathrm{H}_{2}$ increased and reached $17,82 \%$ and quite stabilized. This can prove the stabilization was established. Therefore, straw can have a great effect on the amount of organic compound, former compound of hydrogen producer and through that affect the efficiency of forming hydrogen.

\section{Conclusions}

Through the study, producing hydrogen from straw using biotechnology has proceeded enriching anaerobic bacteria producing hydrogen successfully from natural bacteria source in the condition of thermal shocked with straw added as a carbon source, this lessen the initial investment for the production and able to control the bacteria source.

Using straw, an available agricultural waste to produce hydrogen by fermentation method using natural bacteria source with relatively high efficiency, provide clean energy, simultaneously contribute to reduce polluting the environment, open a new path in producing clean energy.

This method could be applied to industrial production, however, further research is still required to find the optimum condition for producing hydrogen from straws.

\section{Acknowledgements}

This work was funded by the Rosneft Petroleum Company and Hanoi University of Mining and Geology (HUMG). The authors would like to thank H., Thuy Nguyen, Duc, Viet Nguyen, K. A. Bui, H. Thu Tran for technical assistance and support. The facility supports by Hanoi University of Mining and Geology, and Hanoi University of Science and Technology were highly acknowledged.

\section{References}

1. Sherif SA, Barbir F, Veziroglu TN (2006) Wind energy and the hydrogen economy-review of the technology. Solar Energy 78: 155-66.

2. Ye X, Wang Y, Hopkins RC, Adams MW, Evans BR et al. (2009) Spontaneous High-Yield Production of Hydrogen from Cellulosic Materials and Water Catalyzed

by Enzyme Cocktails. ChemSusChem 2: 149-52.

3. Hauch A, Ebbesen SD, Jensen SH, Mogensen M (2008) Highly efficient high temperature electrolysis. J Mater Chem 18: 2331-40.

4. Häussinger P, Lohmüller R, Watson AM (2011) Hydrogen, 1 Properties and Occurrence. Ullmann's Encyclopedia of Industrial Chemistry.

5. Badwal SPS, Giddey S, Munnings C, Bhatt AI, Hollenkamp AF (2013) Hydrogen production via solid electrolytic routes. Wiley Interdisciplinary Reviews: Energy and Environment 2: 473-87.

6. Clarke RE, Giddey S, Ciacchi FT, Badwal SPS, Paul B, et al. (2009) Direct coupling of an electrolyser to a solar PV system for generating hydrogen. International Journal of Hydrogen Energy 34: 2531-42.

7. Hemschemeier A, Melis A, Happe T (2009) Analytical approaches to photobiological hydrogen production in unicellular green algae. Photosynthesis Research 102: 523-40.

8. Zhang YH, Evans BR, Mielenz JR, Hopkins RC, Adams MWW (2007) High-Yield Hydrogen Production from Starch and Water by a Synthetic Enzymatic Pathway. PLoS One 2: e456.

9. Strik DPBTB, Hamelers HVM (Bert), Snel JFH, Buisman CJN (2008) Green electricity production with living plants and bacteria in a fuel cell. International Journal of Energy Research 32: 870-6. 
10. Martín Del Campo JS, Rollin J, Myung S, Chun Y, Chandrayan S, et al. (2013) High-Yield Production of Dihydrogen from Xylose by Using a Synthetic Enzyme Cascade in a Cell-Free System. Angewandte Chemie International Edition 52: 4587-90.

11. Endy D (2005) Foundations for engineering biology. Nature 438: 449-53.

12. Cheong DY, Hansen CL (2006) Bacterial stress enrichment enhances anaerobic hydrogen production in cattle manure sludge. Appl Microbiol Biotechnol 72: 635-43.

13. Hu B, Chen S (2007) Pretreatment of methanogenic granules for immobilized hydrogen fermentation. Int J Hydrog. Energy 32: $3266-73$.

14. Mu Y, Yu HQ, Wang G (2007) Evaluation of three methods for enriching h 2-producing cultures from anaerobic sludge. Enzym Microb Technol 40: 947-53.

15. Rossi DM, da Costa JB, de Souza EA, Peralba MDCR, Samios D, et al. (2011) Comparison of different pretreatment methods for hydrogen production using environmental microbial consortia on residual glycerol from biodiesel. Int J Hydrog Energy 36: 4814-9.

16. Selembo PA, Perez JM, Lloyd WA, Logan BE (2009) Enhanced hydrogen and 1,3-propanediol production from glycerol by fermentation using mixed cultures. Biotechnol Bioeng 104: 1098-106.

17. Wang J, Wan W (2008) Comparison of different pretreatment methods for enriching hydrogen-producing bacteria from digested sludge. Int J Hydrog Energy 33: $2934-41$

18. Adams MWW, Stiefel EI (1998) Biological hydrogen production: Not so elementary. Science 282: 1842-3.

19. Veziroglu TN, Debabrata Das (2001) Hydrogen production by biological processes: a survey of literature. Int J Hydrogen Energy 26: 13-28.

20. Hallenbeck PC, Benemann JR (2002) Biological hydrogen production: fundamentals and limiting processes. Int J Hydrogen Energy 27: 1185-93.

21. Chandrasekhar K, Lee YJ, Lee DW (2015) Biohydrogen production: Strategies to improve process efficiency through microbial routes. Int J Mol Sci 16: 8266-93. 22. Vymazal J, Kröpfelová L (2008) Wastewater Treatment in Constructed Wetlands with Horizontal Sub-Surface Flow.

23. Varrone C, Giussani B, Izzo G, Massini G, Marone A, et al. (2012) Statistical optimization of biohydrogen and ethanol production from crude glycerol by microbial mixed culture. Int J Hydrog Energy 37: 16479-88.

24. Jürgensen L, Ehimen EA, Born J, Holm-Nielsen JB (2015) Hydrogen production using an anaerobic baffled reactor-mass balances for pathway analysis and gas composition profiles. Int J Hydrog Energy 40: 12154-61.

25. Zhang YHP, Lynd LR (2004) Toward an aggregated understanding of enzymatic hydrolysis of cellulose: Noncomplexed ellulose systems. Biotechnol Bioeng 88: $797-824$

26. Zhang YHP, Himmel M, Mielenz JR (2006) Outlook for cellulase improvement: Screening and selection strategies. Biotechnol Adv 24 : $452-81$.

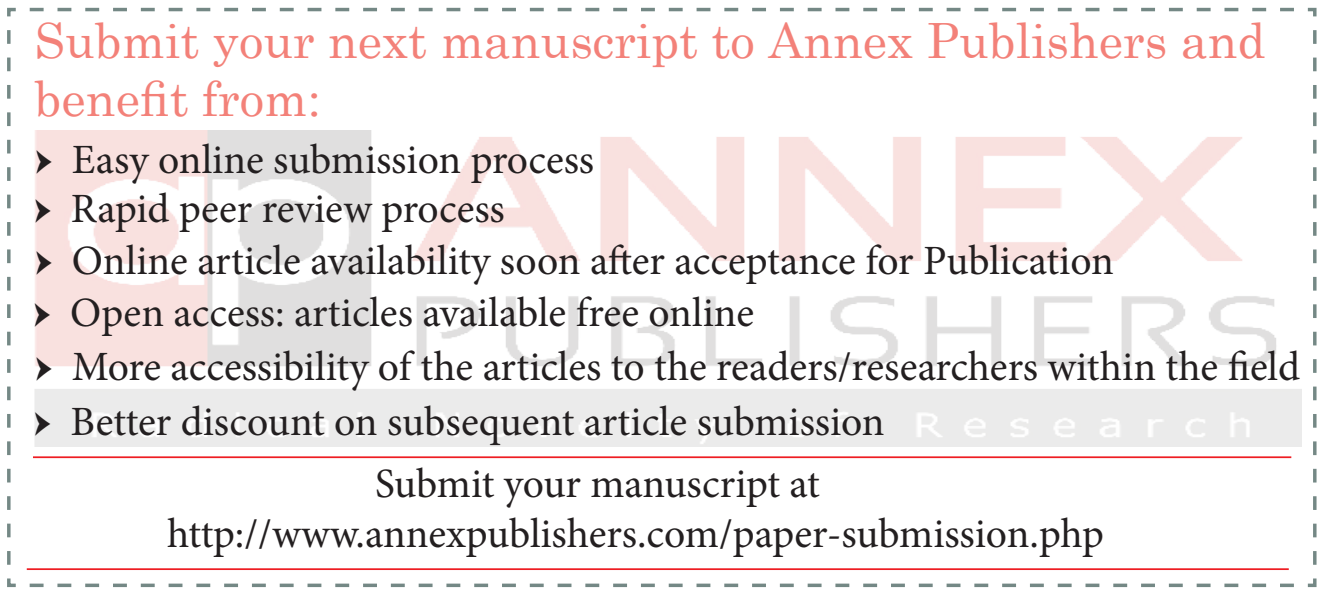

